\title{
Quantitative expression of the homeobox and integrin genes in human gastric carcinoma
}

\author{
DUCCIO ROSSI DEGL'INNOCENTI ${ }^{1}$, FRANCESCA CASTIGLIONE ${ }^{1}$, ANNA MARIA BUCCOLIERO ${ }^{1}$ \\ PAOLO BECHI $^{2}$, GIAN LUIGI TADDEI ${ }^{1}$, GIANCARLO FRESCHI ${ }^{2}$ and ANTONIO TADDEI ${ }^{2}$
}

\author{
Departments of ${ }^{1}$ Human Pathology and Oncology, ${ }^{2}$ Surgical Pathology, \\ School of Medicine, University of Florence, Florence, Italy
}

Received March 16, 2007; Accepted May 23, 2007

\begin{abstract}
The homeobox (HOX) genes are a large family of regulator genes involved in the control of developmental processes and cell differentiation. The HOX genes encode transcription factors, and an increasing number of studies have shown that these genes may be implicated in the growth and the progression of many types of tumours. The present study investigated the expression of the HOX and integrin genes and their relationships in gastric carcinoma. We analyzed the RNA expression of 13 HOX genes from HOXA, $\mathrm{C}$ and D clusters and $\alpha \mathrm{V}, \alpha 5$ and $\alpha 8$ integrin genes in 24 gastric cancer samples by quantitative real-time PCR. The results showed that the HOXA2 gene and the $\alpha 8$ integrin gene had a lower expression in tumour samples than in normal gastric mucosas. The comparison between the HOX and integrin genes showed that HOXA2 and $\alpha \mathrm{V}$ integrin expression presented the same trend in $83 \%$ of the samples. Moreover, in cancer samples that expressed the HOXD11 gene, the expression of $\alpha \mathrm{V}$ integrin was lower with respect to normal mucosas. The different roles of HOX and integrin genes in gastric carcinoma remain to be fully elucidated. These findings suggest that the HOX genes may play a critical role in the genesis, maintenance and diffusion of gastric carcinoma.
\end{abstract}

\section{Introduction}

The homeobox genes were originally discovered in the fruit fly Drosophila (1). Subsequently, they have been found in

Correspondence to: Dr Duccio Rossi Degl'Innocenti, Department of Human Pathology and Oncology, School of Medicine, University of Florence, Viale GB Morgagni 85, 50134 Florence, Italy

E-mail: duccio.rossideglinnocenti@unifi.it

Abbreviations: HD, homeodomain; HOX, homeobox; ECM, extracellular matrix; PCR, polymerase chain reaction; GAPDH, glyceraldehyde-3-phosphate dehydrogenase

Key words: HOX, integrin, gastric cancer, real-time PCR, expression many organisms such as fungi, plants and even vertebrates (2). Homeobox genes are regulatory genes with a common 180- to 183-bp sequence (homeobox) coding for a 61-aminoacid domain defined as homeodomain (HD). This homeodomain is a DNA-binding domain (3) and acts as a transcription factor during normal embryonic development (4). The specificity of this binding activates or represses the expression of patterns of downstream effector target genes (5).

The human class I homeobox genes, also termed HOX genes, are organized into four clusters HOXA, HOXB, HOXC and HOXD and are situated on separate chromosomes; 7, 12, 17 and 2, respectively (6). Each cluster contains between 9 and 11 genes for a total of 39 clustered human HOX genes (7). During development, HOX genes are expressed in accordance with gene position within the cluster and in a rostral-caudal manner (8).

Recently, there has been increased interest regarding the possible role of the human HOX genes, and many studies have attempted to find a relation between inappropriate expression of these genes and tumour progression and metastasis.

Experimental approaches have shown that there is a misexpression of particular HOX genes between normal tissue and malignant tissue in some primary cancers of the kidney, colon and lung (9-12). The HOXB6, HOXB8, HOXC8 and HOXC9 genes are misexpressed at various stages of colon cancer evolution (13), and HOXB7, inactive in normal melanocytes, is expressed in melanomas (14).

An altered pattern of HOX gene expression was found in human skin, in prostate cancer $(15,16)$, in bladder cancer (17) and in invasive breast carcinoma (18). It was associated with the invasive capacity of cancer cells (19). Other studies demonstrated that HOXD9 is inappropriately expressed in esophageal squamous cell carcinoma (20) and in cervical cancer (21).

Moreover, results suggest that HOX gene expression may be related to the expression of surface molecules involved in cell-cell and cell-matrix interaction (22). The HOX genes may also interact with the Ras signaling cascade and the p53 pathway (23).

The HOX genes are also expressed in normal cells to maintain tissue and organ physiology. They have been shown to play a crucial role in the last stages of cell differentiation. The expression of the HOX genes also appeared to be equal 
in the same normal adult tissues of different patients such molecular tissue portrait (10). Some organs even showed similar expression of the HOX genes in both the embryo and the adult, and the organs located at the posterior portion of the body expressed almost all the HOX genes whereas the organs in the anterior portion expressed less than half (24).

The integrins, consisting of an $\alpha$ and a $\beta$ transmembrane subunit, are adhesion receptors that link the extracellular matrix (ECM) to the cytoskeleton. Moreover, they promote cell migration and cell survival cooperating with growth factor receptors (25). The integrins transmit mechanical and chemical signals and organize the cytoskeleton during cell adhesion and migration (26). These receptors can favour cancer cell tumour initiation and progression (27); neoplastic cells enhance the expression of integrins which induce their proliferation and migration, whereas they lose expression of other integrins that have the opposite effects. Pathological changes in integrin expression depend on the origin of the tumour tissue, its histological type and stage (28).

Recent studies have demonstrated that integrins play an important role in gastric carcinoma cell proliferation and migration. The $\alpha 9 ß 1$ integrin seems to mediate mitogenic signals in tumour and stromal cells (29), and the $\alpha 9 \beta 1$ integrin promotes the initial metastasis of gastric carcinoma cells (30). The $\alpha 2$ and $\alpha 6$ intregrins play essential roles in the invasion of different types of gastric cancer cell lines (31), and the $B 4$ integrin shows down-regulation in gastric carcinoma cells from malignant ascites (32). $\alpha 9 \beta 1$ integrin is indispensable for the adhesion of tumour epithelial cells and for their growth and differentiation (29).

Gastric cancer is the second most frequent cancer of the digestive system in Italy and remains the second cause of cancer-related deaths in the world.

The role of the HOX genes in the development of gastric cancer has not been studied, and there are no reports on HOX expression in this kind of tumour. This study aimed to understand the role of the HOX genes in gastric cancer progression. We focused our studies on HOXA2, HOXA4, HOXA9, HOXC6, HOXD1, HOXD3, HOXD4, HOXD8, HOXD9, HOXD10, HOXD11, HOXD12 and HOXD13. We based our analyses of gastric cancer specimens regarding these particular genes on the results of De Vita et al (11) in colorectal cancer.

We studied the HOX genes that showed misexpression as reported by De Vita et al (HOXA2, HOXA4, HOXA9, HOXC6, HOXD1, HOXD4, HOXD11) and we widened the analysis to the other HOXD genes (HOXD3, HOXD8, HOXD9, HOXD10, HOXD12 and HOXD13).

Moreover, we evaluated $\alpha \mathrm{V}, \alpha 5$ and $\alpha 8$ integrin gene expression looking for possible interactions and correlations with the HOX genes.

For the analysis of gene expression, we used quantitative real-time reverse-transcription PCR since it is more sensitive than conventional methods and it may quantify up to a few cDNA copies

\section{Materials and methods}

Patients. Gastric mucosa fragments from 24 consecutive patients (17 males, 7 females, mean age 67 ) were obtained by a cold blade cut from the operative specimens of patients undergoing gastric resection for cancer. Specimens were taken at least $10 \mathrm{~cm}$ from the neoplasm, and gastric mucosa appeared normal at macroscopic evaluation. Patients did not receive pre-operative radiotherapy or chemotherapy and were treated at the Department of Surgical Pathology 1, University of Florence.

All samples were microscopically evaluated and classified as gastric adenocarcinoma and normal gastric mucosa. All tissue pieces were sectioned to ensure that all spatial dimensions were $\leq 10 \mathrm{~mm}(10 \times 10 \times 0.3 \mathrm{~mm})$. All diagnoses were confirmed by examination of 5-micron hematoxylin and eosin-stained sections and all gastric mucosa fragments were macroscopically and histologically whole. The fragments were immersed in RNAlater ${ }^{\mathrm{TM}}$ (Qiagen, Milan, Italy), kept overnight at $4^{\circ} \mathrm{C}$ and stored at $-80^{\circ} \mathrm{C}$ until analysed.

$R N A$ isolation. The tissues $(\sim 5 \mathrm{mg})$ were defrosted and cut in small pieces. The samples were re-suspended in $200 \mu 1$ nucleic acid purification lysis solution (Applied Biosystems, Foster City, CA) and homogenized using a PCR tissue homogenizing kit (PBI International, Milan, Italy) in microcentrifuge tubes. RNA was isolated using 6100 Nucleic Acid PrepStation (Applied Biosystems) and subsequently stored at $-80^{\circ} \mathrm{C}$. RNAs were quantified by spectrophotometer at an OD

Table I. Features of all clinical specimens. ${ }^{\mathrm{a}}$

\begin{tabular}{ccclc}
\hline Patient & Sex & Age & \multicolumn{1}{c}{ Site } & Stage \\
\hline 1 & M & 56 & Antrum-lesser curve & G3 \\
2 & M & 58 & Subcardial & G3 \\
3 & M & 51 & Antrum-corpus-fundus & G3 \\
4 & M & 52 & Corpus-fundus & G3 \\
5 & M & 75 & Cardias-pyloric antrum & G3 \\
6 & M & 69 & Stump & G2 \\
7 & M & 76 & Anterior wall, antrum & G3 \\
8 & M & 74 & Stump & G3 \\
9 & F & 81 & Lesser curve & G3 \\
10 & M & 56 & Antrum & G3 \\
11 & M & 81 & Corpus-antrum & G3 \\
12 & M & 61 & Corpus & G3 \\
13 & M & 74 & Fundus & G2 \\
14 & F & 84 & Antrum & G2 \\
15 & F & 45 & Antrum-lesser curve & G3 \\
16 & F & 48 & Antrum & G3 \\
17 & F & 67 & Antrum-pylorus & G3 \\
18 & F & 85 & Antrum & G2 \\
19 & M & 81 & Stump & G2 \\
20 & F & 61 & Antrum & G2 \\
21 & M & 78 & Cardias & G2 \\
22 & M & 62 & Cardias & G3 \\
23 & M & 78 & Cardias & G3 \\
24 & M & 71 & Antrum-lesser curve & \\
\hline
\end{tabular}

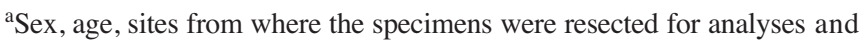
tumour stages at operation, according to the WHO classification of tumours. 

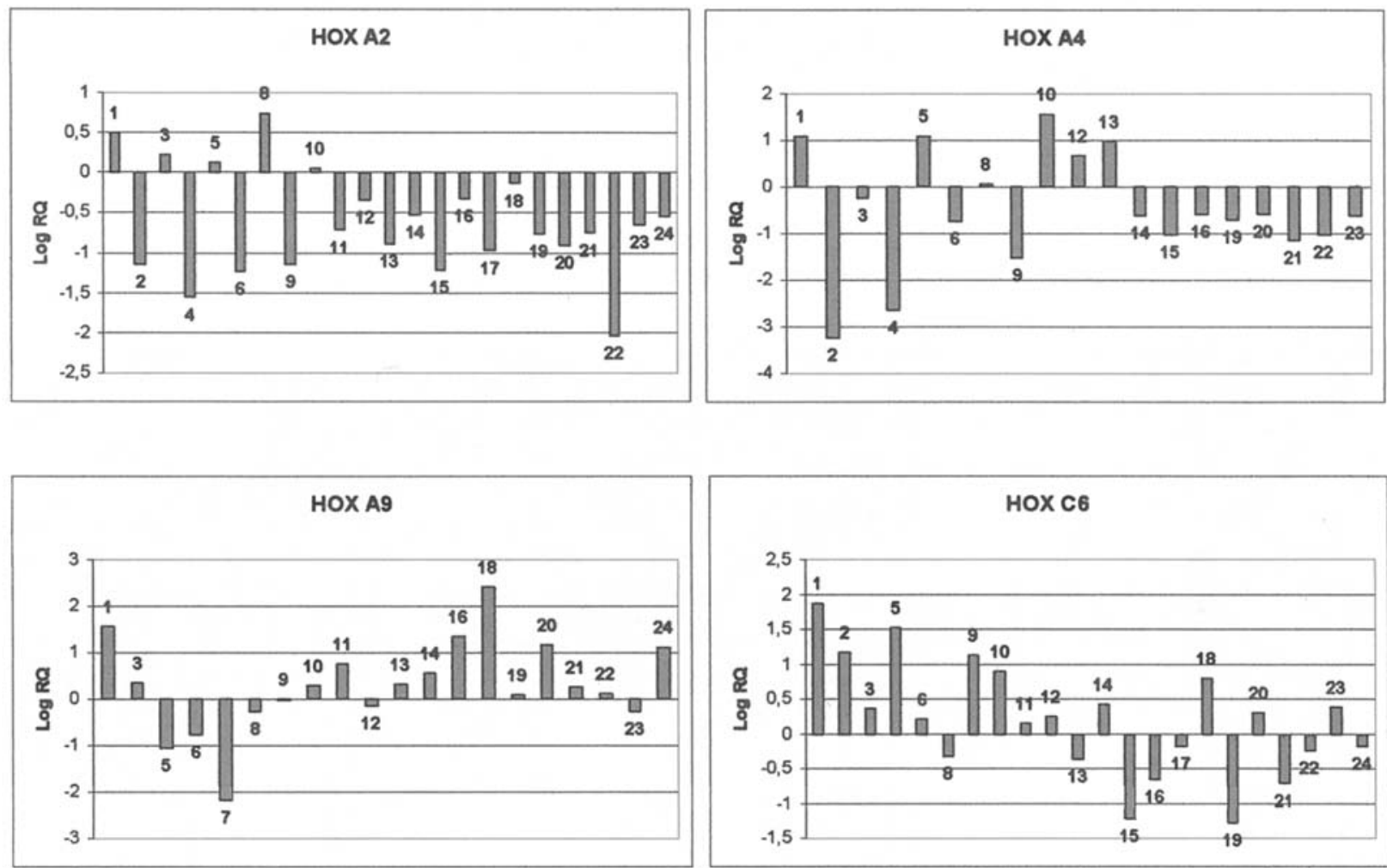

Figure 1. Relative expression of HOXA2, HOXA4, HOXA9 and HOXC6 genes in gastric adenocarcinoma with respect to normal gastric mucosa. The graphs display only the cases which show expression in both gastric adenocarcinoma and normal gastric mucosa.

of $260 \mathrm{~nm}$, and the RNA fragmentation state was evaluated by $1.5 \%$ agarose gel.

Real-time quantitative PCR. All RNA samples (500 ng) were reverse transcribed to cDNA using a High Capacity cDNA Archive kit (Applied Biosystems) according to the manufacturer's protocol. In the RT reaction a negative control was performed.

TaqMan real-time quantitative PCR was performed on an ABI PRISM 7000 sequence detector system (Applied Biosystems). PCR products for the HOXA2, HOXA4, HOXA9, HOXC6, HOXD1, HOXD3, HOXD4, HOXD8, HOXD9, HOXD10, HOXD11, HOXD12, HOXD13, $\alpha \mathrm{V}$ integrin, $\alpha 5$ integrin and $\alpha 8$ integrin genes were detected using gene-specific primers and probes labelled with reporter day FAM (Assay on Demand, Applied Biosystems). The GAPDH (glyceraldehyde-3-phosphate dehydrogenase) gene was used as an endogenous control gene for normalization and was detected using gene-specific primers and probes labelled with reporter day VIC (Applied Biosystems).

The PCR reaction was carried out in triplicate on 96-well plates with $20 \mu 1$ per well using $1 \mathrm{X}$ TaqMan Universal PCR MasterMix. After an incubation for $2 \mathrm{~min}$ at $5^{\circ} \mathrm{C}$ and $10 \mathrm{~min}$ at $95^{\circ} \mathrm{C}$, the reaction was continued for 50 cycles at $95^{\circ} \mathrm{C}$ for $15 \mathrm{sec}$ and $60^{\circ} \mathrm{C}$ for $1 \mathrm{~min}$.

Analysis of the results. At the end of the reaction, the results were evaluated using the ABI 7000 PRISM software, and the $\mathrm{Ct}$ values were exported to Microsoft Excel. The $2^{-\Delta \Delta \mathrm{Ct}}$ method described by Livak and Schmittgen (33) was used to analyse the results. The $\mathrm{Ct}$ values for each set of three reactions were averaged for all subsequent calculations. For each sample of gastric cancer, the specimen of normal gastric mucosa from the same patient was used as the control.

Statistical analysis. The shift in the relative expression level of the genes in gastric cancer and normal gastric mucosa was calculated according to the Wilcoxon-Mann-Whitney test. Data analysis was performed using SPSS version 14.0 (Chicago, IL) statistical package. A $\mathrm{P}$ value $\leq 0.05$ was considered to be statistically significant.

\section{Results}

We analysed 48 samples from 24 consecutive patients, taking a specimen from the gastric cancer and a specimen from normal mucosa for each patient. The patients, 17 males and 7 females, were from 45 to 85 years of age (mean age 67 ). Sixteen cases had G3 stage disease (low-grade differentiation) according to WHO classification of tumours, and eight cases had G2 stage disease (medium-grade differentiation). The specimens were resected from different gastric sites (Table I).

Real-time PCR of the HOX and integrin genes - qualitative analysis. We successfully extracted RNA from all samples. The RNA concentration and purity were quantitated spectrophotometrically by measuring their absorbance at 260 and $280 \mathrm{~nm}$. The isolated RNA was transcribed to cDNA and amplified by real-time PCR in all cases. The RNA signal was 
Table II. Qualitative gene expression of HOX and integrins. ${ }^{a}$

\section{Patient}

\begin{tabular}{|c|c|c|c|c|c|c|c|c|c|c|c|c|c|c|c|c|c|c|c|c|c|c|c|c|c|}
\hline & & 1 & 2 & 3 & 4 & 5 & 6 & 7 & 8 & 9 & 10 & 11 & 12 & 3 & 14 & 15 & 6 & 17 & 18 & 19 & 20 & 21 & 22 & 23 & 24 \\
\hline & $C$ & 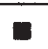 & $\mathbf{\square}$ & $n$ & $n$ & 口 & $\mathbf{v}$ & a & . & घ & $\mathbf{v}$ & 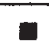 & 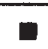 & घ & ש & च & 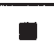 & E & m & a & a & a & a & a & $\mathbf{a}$ \\
\hline & $M$ & 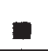 & a & " & $\mathbf{m}$ & 口 & n & 0 & ( & 口 & 口 & 口 & $=$ & a & - & a & ט & E & $=$ & a & ש & ש & a & v & ש \\
\hline & $C$ & - & $\square$ & $\bar{\square}$ & $\square$ & $\bar{\square}$ & $\overline{1}$ & $\bar{E}$ & $\bar{E}$ & $\square$ & a & 0 & $\mathbf{n}$ & $\square$ & 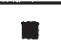 & 0 & $\square$ & 0 & 0 & $\square$ & D & D & $\square$ & ש & 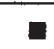 \\
\hline & $M$ & घ & a & $\square$ & $\square$ & - & 口 & 0 & 口 & घ & $\square$ & 口 & 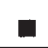 & $a$ & w & $\square$ & a & a & ○ & E & $\mathbf{a}$ & $\mathbf{n}$ & a & a & च \\
\hline & $C$ & 口 & $\square$ & $\square$ & घ & a & $\square$ & a & I & $\square$ & $\square$ & $\square$ & $\square$ & I & D & - & $\square$ & $\square$ & 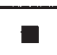 & 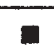 & $\square$ & $\square$ & ט & D & $\square$ \\
\hline & $M$ & - & 0 & 口 & o & घ & a & घ & E & a & 口 & घ & - & घ & 口 & 0 & a & 0 & Ш & ص & v & Ш & a & घ & घ \\
\hline n】 & $C$ & च & $\square$ & a & $\square$ & I & 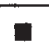 & 口 & a & a & 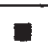 & a & E & a & a & a & $\square$ & $\mathbf{E}$ & 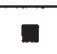 & a & $\square$ & घ & a & - & 口 \\
\hline U: & $M$ & a & $a$ & $\square$ & 0 & a & a & 0 & a & v & $\square$ & a & च & $a$ & - & E & a & E & ㅁ & a & घ & a & च & a & घ \\
\hline HO & $C$ & $\square$ & 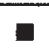 & $\square$ & 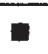 & 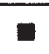 & $\bar{\square}$ & $\mathbf{v}$ & (1) & a & घ & (1) & a & 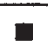 & (1) & $\square$ & 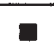 & E & 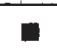 & a & 口 & $\vec{\square}$ & 口 & 口 & $\square$ \\
\hline & $M$ & 口 & a & 口 & $=$ & E & 口 & 口 & - & 口 & 口 & a & E & a & - & - & $\square$ & - & a & a & 口 & 口 & 口 & - & \\
\hline HOXn? & $C$ & $\square$ & $=$ & 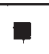 & 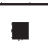 & I & $\square$ & $\square$ & I & $\square$ & I & $\square$ & I & च & $\square$ & $\square$ & $\square$ & a & $\square$ & $\square$ & $\square$ & $\square$ & $\square$ & $\square$ & $\bar{\square}$ \\
\hline & $M$ & 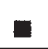 & a & 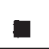 & 0 & E & a & $\square$ & a & a & $\mathbf{a}$ & a & a & a & 口 & $\mathbf{E}$ & $\mathbf{a}$ & a & a & a & $\boldsymbol{\square}$ & 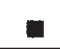 & a & घ & a \\
\hline & $C$ & $\square$ & 口 & $\square$ & $\square$ & $\square$ & - & $\bar{\square}$ & ש & $\square$ & $\square$ & $\square$ & 0 & $\square$ & 0 & E & $\square$ & 0 & 0 & $\square$ & $\square$ & 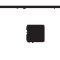 & 0 & 0 & 0 \\
\hline & $M$ & E & 口 & 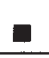 & $\circ$ & 무요 & $=$ & 0 & 口 & E & = & 口 & 口 & $=$ & 口 & 0 & 0 & 0 & 0 & 0 & 口 & 0 & 0 & 0 & 0 \\
\hline & $C$ & a & घ & $\square$ & $\square$ & a & घ & 0 & D & a & $\square$ & a & $\square$ & a & E & I & I & a & a & a & a & $\square$ & a & 口 & E \\
\hline & $M$ & a & a & a & a & a & a & a & a & a & a & 口 & च & a & a & च & a & 0 & $\square$ & च & $a$ & a & a & - & - \\
\hline & $C$ & 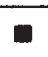 & a & $\mathbf{E}$ & a & a & $\square$ & 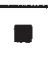 & a & E & $\dot{\square}$ & $\square$ & a & D & घ & $\square$ & $\square$ & 口 & I & a & $\square$ & a & 口 & a & $\square$ \\
\hline 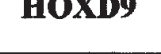 & $M$ & a & घ & a & o & घ & ט & 0 & 口 & a & a & 口 & a & - & घ & E & घ & o & a & घ & 口 & 口 & a & ص & - \\
\hline $\mathbf{H}$ & $C$ & $\square$ & I & a & $\square$ & I & $\square$ & $\square$ & $\square$ & $\square$ & a & a & ( & a & $\square$ & I & a & E & $\square$ & a & 0 & $\square$ & $\square$ & 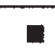 & $\square$ \\
\hline & $M$ & a & a & $\square$ & 0 & a & n & 0 & E & 0 & a & 0 & च & a & E & 0 & च & a & 0 & 口 & a & 0 & a & a & a \\
\hline $\boldsymbol{F}$ & $C$ & 0 & 0 & 0 & $\square$ & $\square$ & 口 & E & 0 & $\square$ & 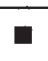 & $\mathbf{\square}$ & 0 & $\square$ & $\square$ & 0 & 0 & $\square$ & E & 0 & 0 & 0 & D & v & 0 \\
\hline & $M$ & 0 & 0 & 0 & 0 & 0 & 0 & 0 & ש & 0 & 0 & 0 & 0 & 0 & 0 & 0 & 0 & 0 & 0 & 0 & $\circ$ & 0 & 0 & 0 & o \\
\hline $\mathbf{I}$ & $C$ & a & च & a & - & I & a & च & I & घ & a & I & a & I & U & a & a & ש & च & a & च & $\square$ & a & च & $\square$ \\
\hline & $M$ & a & घ & a & a & a & a & = & a & a & - & a & E & a & E & E & 口 & - & 口 & - & $\square$ & ㅁ & a & 口 & 口 \\
\hline 13 & $C$ & 0 & 0 & 0 & a & U & 0 & 口 & 0 & 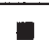 & 0 & a & 0 & 0 & 0 & 0 & 0 & 0 & a & I & $\square$ & $\square$ & $\square$ & 0 & 0 \\
\hline & $M$ & 0 & च & a & 0 & 0 & ש & 0 & 0 & च & 0 & 0 & 0 & 0 & ט & 0 & 0 & 0 & 0 & 0 & 0 & 0 & 0 & a & 0 \\
\hline $\mathbf{V} \mathbf{V}$ interrin & $C$ & a & a & 口 & $\mathbf{v}$ & E & a & 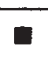 & 口 & a & 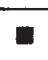 & a & 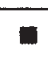 & $\square$ & $\square$ & $\square$ & $\square$ & $\square$ & $\square$ & $\square$ & $\square$ & $\square$ & $a$ & ( & $\square$ \\
\hline & $M$ & $\mathbf{m}$ & E & a & a & $\square$ & a & 口 & a & a & a & $\square$ & 口 & - & 口 & a & a & $\mathbf{a}$ & $\mathbf{a}$ & a & $\square$ & u & a & a & . \\
\hline 05 inteorin & $C$ & $\square$ & $\square$ & $\mathbf{n}$ & $\square$ & D & 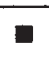 & $=$ & - & $\square$ & 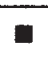 & $\mathbf{0}$ & 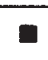 & $\square$ & a & $\square$ & $\square$ & $\square$ & $\square$ & 0 & $\square$ & $\square$ & $\square$ & 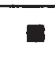 & a \\
\hline as integnn & $M$ & $\square$ & a & a & a & E & $\square$ & D & a & $\square$ & घ & a & 口 & $=$ & a & - & - & E & $\square$ & - & D & घ & $\mathbf{a}$ & 口 & m \\
\hline 08 integr & $\bar{C}$ & E & $E$ & E & $\boldsymbol{\square}$ & E & $\square$ & a & $\boldsymbol{\square}$ & $\square$ & D & $\square$ & $\square$ & $\pi$ & $\square$ & $\square$ & $\square$ & $\square$ & $\square$ & $\square$ & $\square$ & E & $\square$ & 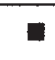 & $\square$ \\
\hline as integr & $M$ & a & E & 口 & $=$ & E & - & - & E & - & a & a & $\mathbf{E}$ & a & a & a & a & a & 口 & च & a & - & a & a & 口 \\
\hline
\end{tabular}

${ }^{a}$ The presence/absence of gene expression in all patients and in all cancer and normal tissues. C, gastric cancer; M, normal gastric mucosa; - presence of HOX expression; $\bigcirc$ absence of HOX expression.

not detected for any marker in the negative controls. Gene expression was measured with regard to the housekeeping gene (GAPDH). For each patient, expression of each gene in gastric cancer was compared with expression in normal gastric mucosa.

Expression of the HOXA2, HOXA4, HOXA9, HOXC6, HOXD1, HOXD3, HOXD4, HOXD8, HOXD9, HOXD10, HOXD11, HOXD12, HOXD13, $\alpha \mathrm{V}$ integrin, $\alpha 5$ integrin and $\alpha 8$ integrin genes is reported in a qualitative manner in Table II.

The HOXA2 gene was expressed in all samples except in 1 normal mucosa (case 7). HOXA4 gene expression was present in 20 gastric cancers and in 22 normal mucosa (in case 18 it was absent in both samples). HOXA9 gene expression was present in all gastric cancers and in 20 normal mucosas. The HOXC6 gene was expressed in all samples except 2 normal mucosas. HOXD3 gene expression was present in all samples except 1 normal mucosa. HOXD4 expression was observed in $71 \%$ of gastric cancers (17 cases) and in $54 \%$ of normal gastric mucosas (13 cases); in 5 cases it was absent in both samples. The HOXD8 gene was expressed in all but 1 mucosa and 1 cancer sample. All gastric cancer tissues showed HOXD9 expression and the normal mucosa tissues exhibited HOXD9 expression in 21 cases $(87 \%)$. All cancer tissues except 1 showed HOXD10 expression, while the normal tissues showed expression in 17 

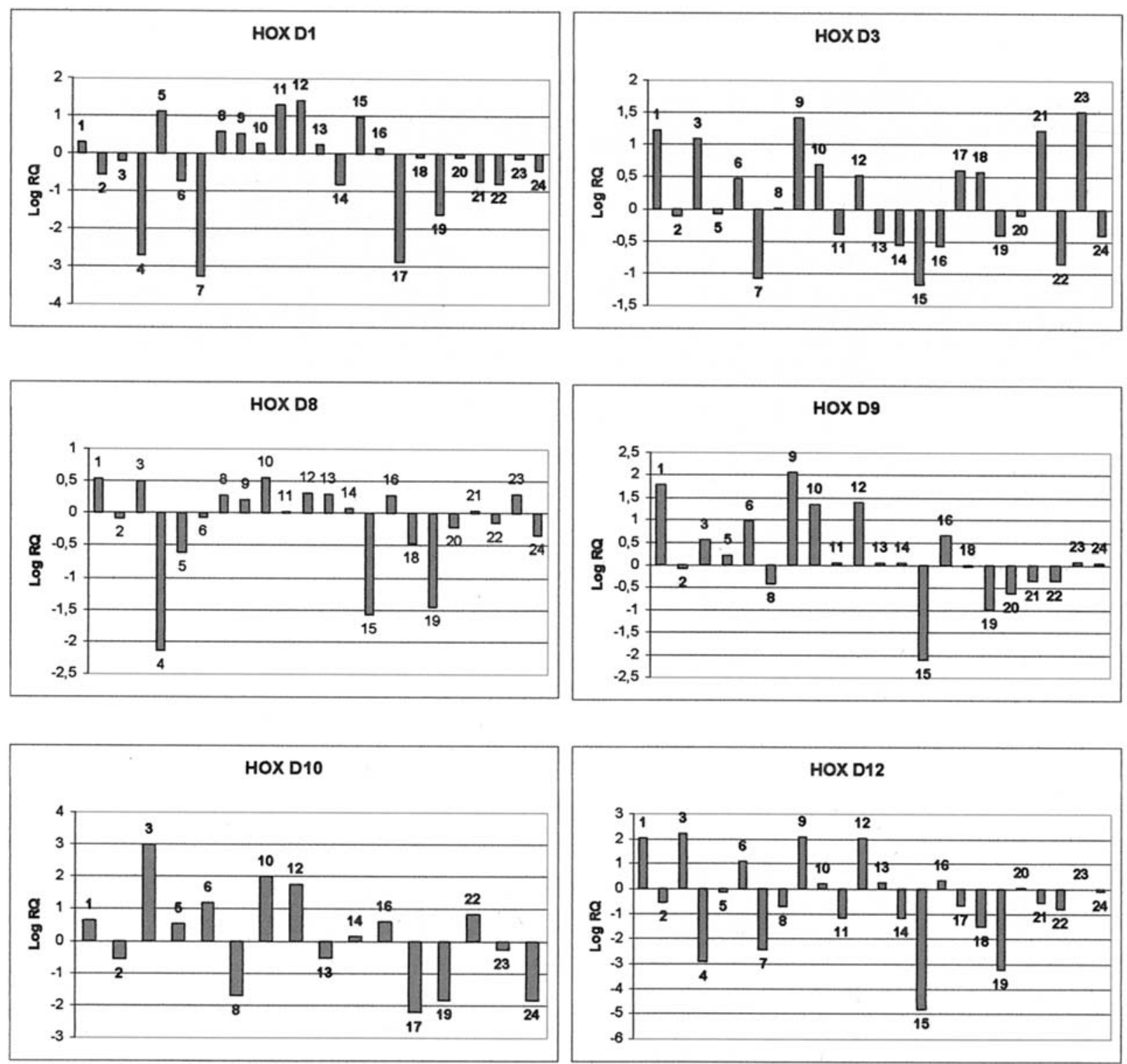

Figure 2. Relative expression of HOXD1, HOXD3, HOXD8, HOXD9, HOXD10 and HOXD12 genes in gastric adenocarcinoma with respect to normal gastric mucosa. The graphs display the cases which show expression in both gastric adenocarcinoma and normal mucosa.

samples $(71 \%)$. HOXD11 expression was present in 54\% of gastric cancers (13 cases) but in only one normal mucosa. Only 10 gastric cancer and 6 normal mucosa tissues showed HOXD13 gene expression. The expression of HOXD1, HOXD12 and all integrin genes was present in all specimens.

Real-time PCR of the HOX and integrin genes - quantitative analysis. Nineteen of the 24 tumour samples expressed the HOXA2 gene at a lower level than normal mucosa. The mean of this gene expression in gastric cancer was $66 \%$ lower with respect to expression in normal mucosa in the cases that expressed the gene in both samples $(\mathrm{P}<0.001)$ (Fig. 1).

For the HOXA4 gene, 6 tumour cases showed higher expression than the normal mucosa (maximum, 1.5 times higher), whereas 13 cases showed reduced expression (maximum, 3.2 times lower). The mean of HOXA4 gene expression was $56 \%$ lower in cancer tissues compared to normal mucosa $(\mathrm{P}=0.156)$ (Fig. 1). For the HOXA9 gene, 6 tumour cases showed an expression lower than the normal mucosa (maximum, 2.1 times lower), whereas 12 cases showed higher expression (maximum, 2.4 times higher). The mean of HOXA9 gene expression was $23 \%$ higher in cancer tissues with respect to normal mucosa $(\mathrm{P}=0.079)$ (Fig. 1). The mean of HOXC6 expression in tumour tissue was $17 \%$ higher with respect to normal mucosa. Thirteen tumour samples expressed higher levels of the HOXC6 gene than normal mucosa (maximum, 1.9 times higher), and nine cases showed lower expression (maximum, 1.3 times lower) $(\mathrm{P}=0.26)$ (Fig. 1).

The HOXD1 gene showed in gastric cancer an expression ranging from 3.2 times lower to 1.4 times higher with respect to normal mucosa (mean, 34\% lower) $(\mathrm{P}=0.339)$ (Fig. 2). The mean of HOXD3 expression in tumour tissue was $14 \%$ higher with respect to normal mucosa. Twelve tumour samples showed lower expression of the HOXD3 gene (maximum, 1.2 times), and eleven showed higher expression than normal mucosa ( $\mathrm{P}=0.412$ ) (Fig. 2).

Regarding HOXD4 gene expression, we obtained no uniform data and only 11 cases expressed this gene in both normal mucosa and gastric cancer (data not shown). The 


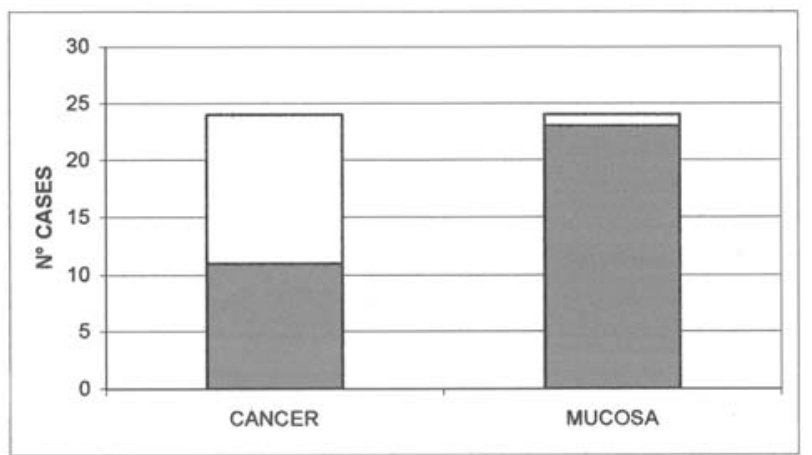

Figure 3. Qualitative analysis of HOXD11 gene expression in gastric mucosa and cancer. Out of a total of 24 cases, 13 gastric cancer samples showed HOXD11 expression (white) while only 1 mucosa sample showed HOXD11 expression.

mean of HOXD8 and HOXD9 expression in tumour tissue with respect to normal mucosa was $16 \%$ lower and $20 \%$ higher respectively, but the cases did not display a uniform trend ( $\mathrm{P}=0.833$ and $\mathrm{P}=0.339$ respectively) (Fig. 2).

The HOXD10 gene displayed in gastric cancer an expression ranging from 2.2 times lower to 3 times higher with respect to normal mucosa (mean, $11 \%$ higher) ( $\mathrm{P}=0.679)$ (Fig. 2). For the HOXD12 gene, 9 tumour cases showed an expression higher than that in normal mucosa, whereas 13 cases showed reduced expression; the mean was 42\% lower ( $\mathrm{P}=0.219)$ (Fig. 2).

Concerning HOXD11 and HOXD13 expression, we were unable to analyse the results because no case showed expression in both normal mucosa and gastric cancer. To note, HOXD11 gene expression was present in 13 specimens of gastric cancer but not in normal mucosa (except case 8) (Fig. 3).

The $\alpha \mathrm{V}, \alpha 5$ and $\alpha 8$ integrins showed reduced gene expression in gastric cancer compared to normal mucosa (22, 22 and $78 \%$ lower, respectively) (Fig. 4). For the $\alpha \mathrm{V}$ integrin, 17 tumour samples expressed at a lower level than normal tissues (maximum 1.6 times) ( $\mathrm{P}=0.059$ ), whereas for $\alpha 5$ integrin, half the tumour samples expressed at a lower level than normal mucosas (maximum, 2.1 times) $(\mathrm{P}=0.265)$. Notably, $20(83 \%)$ gastric cancer cases showed reduced expression of the $\alpha 8$ integrin gene compared with that in normal gastric mucosas $(\mathrm{P}<0.001)$.

Relationships between the HOX and integrin genes. Relative expression of all the HOX genes was compared to the pattern of integrin gene expression, and only the statistically significant relationships were reported in this section. Fig. 5 shows the patterns of HOXA2 and $\alpha \mathrm{V}$ integrin expression. Nineteen of the 23 samples expressed both genes showing the same trend $(\mathrm{P}=0.003)$. Only four cases showed a discordant result.

Moreover, the presence of HOXD11 gene expression in tumour samples was compared with $\alpha \mathrm{V}$ integrin as well. In all but 1 gastric carcinoma sample that expressed the HOXD1 1 gene (12 cases), the expression of $\alpha \mathrm{V}$ integrin was lower in the tumour samples with respect to normal mucosas $(\mathrm{P}=0.002)$.
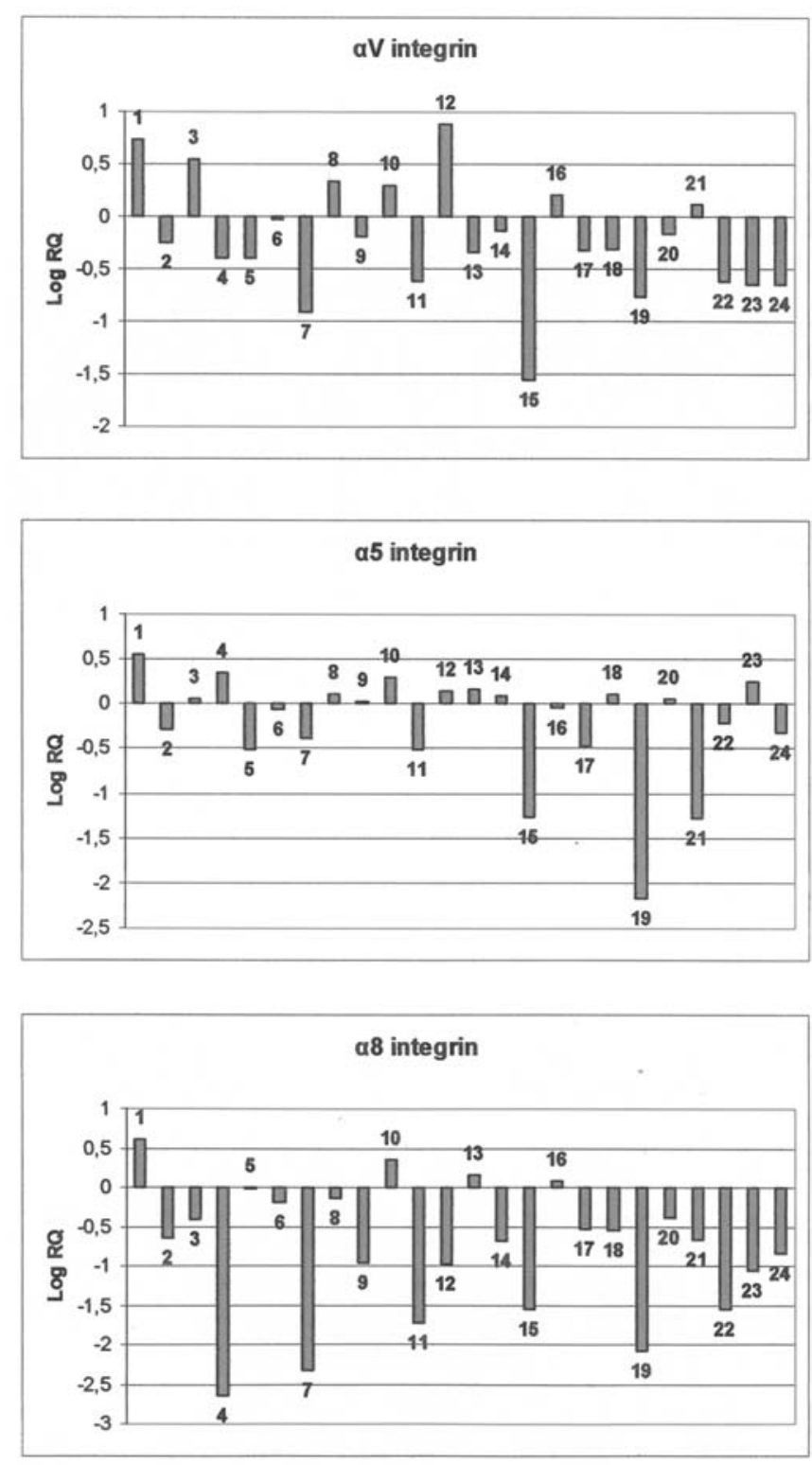

Figure 4. Relative expression of the $\alpha \mathrm{V}$ integrin, $\alpha 5$ integrin and $\alpha 8$ integrin genes in gastric adenocarcinoma with respect to normal gastric mucosa.

\section{Discussion}

Gastric carcinoma is the second most common tumour in the world. Its incidence, however, varies widely, being particularly high in countries such as Japan, P.R. China, the UK and the US. It is more common in lower socioeconomic groups (34). The major factors thought to affect the genesis of gastric cancer are infection by Helicobacter pylori, diet, low socioeconomic status and cigarette smoking. These apply more to the intestinal type, as the risk factors for diffuse gastric cancer are not as well defined.

All HOX genes play an important role in cellular physiology during normal development and in adult mammal life. These genes code for proteins acting as transcription factors which interact with other regulatory proteins, creating a complex network difficult to understand. HOX gene misexpression or mutations can deregulate most cellular processes 


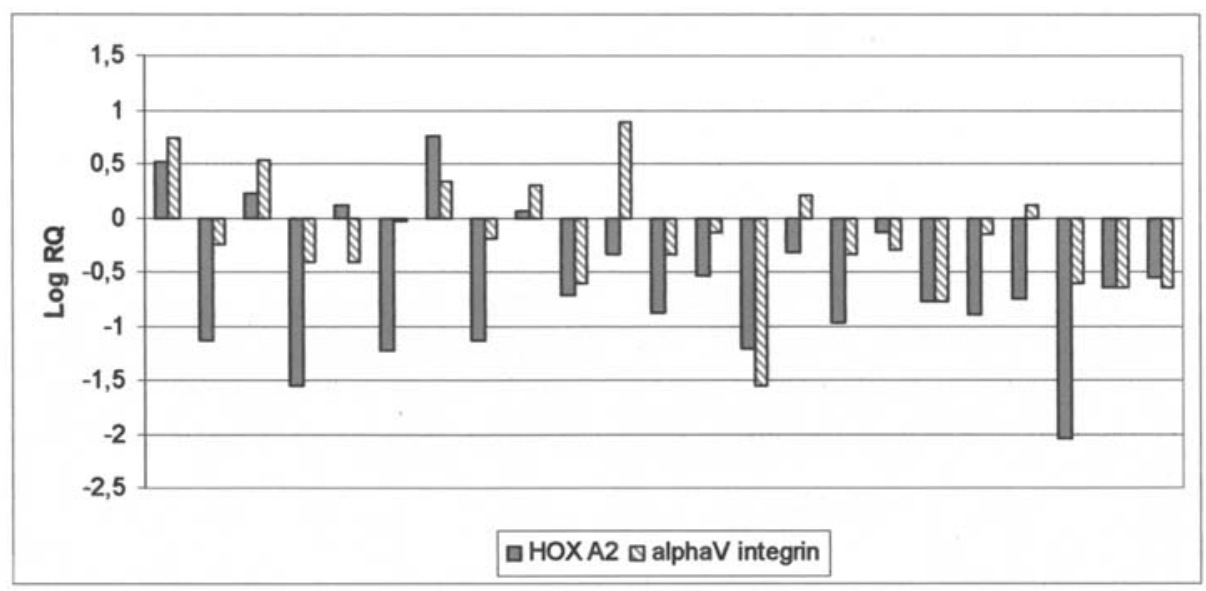

Figure 5. Relative expression of HOXA2 and $\alpha \mathrm{V}$ integrin. Eighty-two percent of the samples showed a relationship between the two genes. The HOXA2 and $\alpha \mathrm{V}$ integrin gene expression seemed to display the same trend in the pathological tissues with respect to normal mucosas.

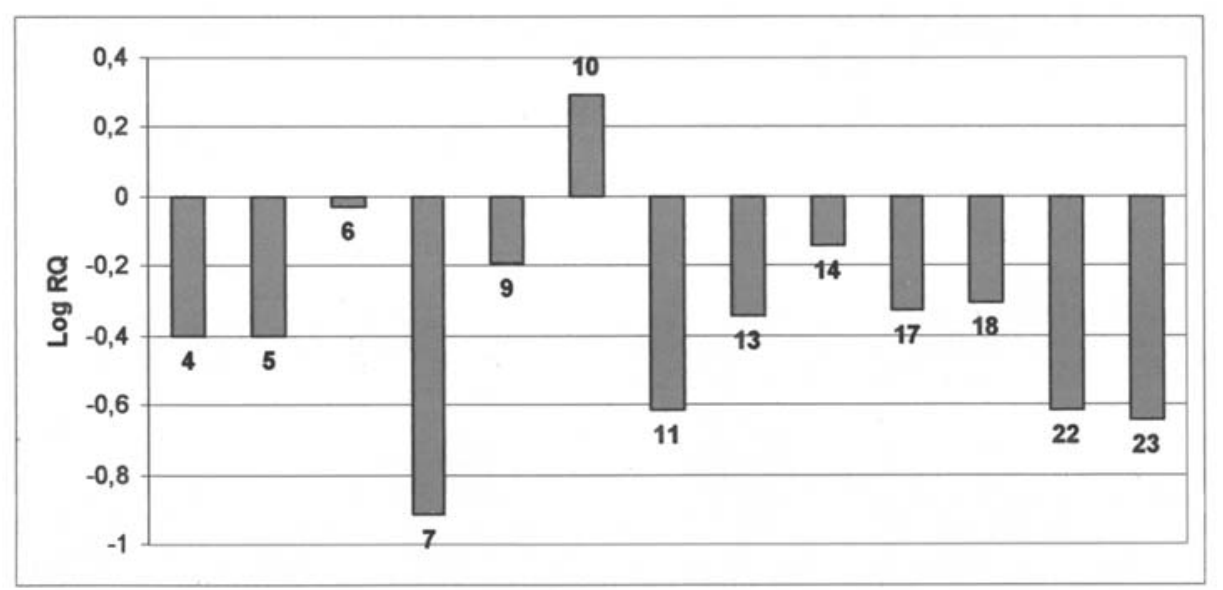

Figure 6. Expression of the $\alpha \mathrm{V}$ integrin gene in samples that showed the presence of HOXD11 expression. All samples except 1 showed lower HOXD11 expression in cancer tissues with respect to normal tissues.

such as proliferation, growth and differentiation; these alterations are crucial in cancer development.

Changes in the expression pattern of the HOX genes were found in colon, lung and cervical cancer, in malignant melanoma and in breast carcinoma $(9,11,18,21,35)$.

However, no previous study has reported HOX gene expression in gastric carcinoma where these genes played an important role. Our aim was to understand the role of the HOX genes in gastric cancer and the possible correlations with gene expression of integrins, proteins involved in cell communication and adhesion. Actually the expression of proteins involved in cell-matrix interaction, such as integrins and ICAM (intercellular adhesion molecule), may be related to the patterns of HOX gene expression (22). In particular Boudreau and Varner showed that $\alpha 5$ integrin expression during angiogenesis was regulated in vivo and in vitro by HOXD3 (36).

Our first notable finding concerned HOXA2 gene expression. Approximately $78 \%$ of the samples expressed the HOXA2 gene at lower levels in tumour tissues than in normal gastric mucosa. Therefore, the DNA-binding transcription factor encoded by the HOXA2 gene appears to have reduced activity in gastric carcinoma. A similar expression pattern was found in invasive breast carcinoma (18) in which HOXA2 and other HOX genes showed down-regulation. However the expression level of HOXA2 in melanoma with distant metastasis was higher than that in cutaneous melanoma without metastasis (35), even though the pattern of HOXA2 expression in cutaneous melanoma with respect to normal skin requires further investigation.

Concerning the HOXD11 gene, we analysed the data in a qualitative manner. Notably, only one sample showed expression in normal mucosa whereas $54 \%$ of the carcinoma samples did. Thus, it appears that the HOXD11 gene is transcribed in gastric carcinoma in an abnormal manner suggesting its important role in the development of this disease. The cell pathways that involve the HOXD11 gene are not yet clearly understood. Davis et al demonstrated that the paralogous HOXD11 and HOXA11 genes are functionally redundant, and they have a similar role in mouse development (37). These paralogous genes play a critical role in nephrogenesis (38) and in neonatal uterine development, 
regulating cellular proliferation and apoptotic responses (39); these functions can be mediated by HOXA11/HOXD11 even in gastric cancer.

The other HOX genes demonstrated neither interesting nor significant patterns of expression.

Concerning integrin expression, we observed a statistically significant correlation between the $\alpha \mathrm{V}$ integrin and HOXA2 genes except in 4 cases (Fig. 5). The $\alpha \mathrm{V}$ integrin gene expression had a similar trend compared to HOXA2 gene expression; the expression of both genes in the same samples was lower or higher in gastric carcinoma than in normal mucosa.

The $\alpha \mathrm{V}$ integrin appears to play a major role in tumour progression. This integrin is essential to cellular migration $(40,41)$, and it may contribute to angiogenesis (42) and survival in metastatic cells (43). On the other hand, the $\alpha \mathrm{VB1}$ integrin mediates the effects of the fibronectin, a matrix glycoprotein that regulates important cellular pathways such as proliferation and adhesion (44). Therefore we assume that the HOXA2 gene, encoding for a transcription factor, can influence the $\alpha \mathrm{V}$ integrin expression directly or indirectly.

Moreover, we found another possible interaction for this integrin by analysis of the correlation with HOXD11. In all tumour cases but one expressing the HOXD11 gene, the expression level of $\alpha \mathrm{V}$ integrin was lower in the tumour samples with respect to normal mucosa.

Thus we suggest that there is a regulation pathway of the $\alpha \mathrm{V}$ integrin gene by HOXD11, even if the expression pattern of the $\alpha \mathrm{V}$ integrin in tumours contrasts with the functions that this protein seems to have in neoplastic cells (40-43). However, further analysis is necessary to confirm these data.

Another significant finding was the down-regulation of the $\alpha 8$ integrin gene in $80 \%$ of the gastric cancer samples. Other studies showed that, in $\alpha 8$ integrin-deficient mesangial cells, cellular adhesion was inhibited whereas migration and proliferation were promoted (45), and that, in vascular smooth muscle cells, a reduction of this integrin by short interference mRNA increased migration but not proliferation (46). These data indicate the importance of $\alpha 8$ integrin in the maintenance of cellular physiology; the reduced expression of this gene may contribute to tumour insurgence, altering important cellular processes such as proliferation and migration.

No relationship was found between the HOX or integrin gene expression patterns and the gastric sites of resection or tumour stage.

The different roles of the HOX and integrin genes in gastric carcinoma, and in other pathologies as well, require further elucidation due to the complex mechanisms and to the large number of genes involved in these pathways.

The results presented in this study are preliminary and certainly require further investigation via different approaches, to understand the cellular processes involved. This study, the first to investigate the expression of the HOX genes in gastric cancer, shows that the HOX and integrin genes may play a critical role in the genesis, maintenance and diffusion of gastric carcinoma.

\section{References}

1. Lewis EB: A gene complex controlling segmentation in Drosophila. Nature 276: 565-570, 1978.

2. Manak JR and Scott MP: A class act: conservation of homeodomain protein functions. Dev Suppl 61-77, 1994

3. McGinnis W and Krumlauf R: Homeobox genes and axial patterning. Cell 68: 283-302, 1992.

4. Gehring WJ and Hiromi Y: Homeotic genes and the homeobox. Annu Rev Genet 20: 147-173, 1986.

5. Boersma CJ, Bloemen M, Hendriks JM, van Berkel EA, Olijve W and van Zoelen EJ: Homeobox proteins as signal transduction intermediates in regulation of NCAM expression by recombinant human bone morphogenetic protein-2 in osteoblast-like cells. Mol Cell Biol Res Commun 1: 117-124, 1999.

6. Boncinelli E, Somma R, Acampora D, et al: Organization of human homeobox genes. Hum Reprod 3: 880-886, 1988.

7. Mark M, Rijli FM and Chambon P: Homeobox genes in embryogenesis and pathogenesis. Pediatr Res 42: 421-429, 1997.

8. Graham A, Papalopulu N and Krumlauf R: The murine and Drosophila homeobox gene complexes have common features of organization and expression. Cell 57: 367-378, 1989.

9. Calvo R, West J, Franklin W, et al: Altered HOX and WNT7A expression in human lung cancer. Proc Natl Acad Sci USA 97: 12776-12781, 2000

10. Cillo C, Barba P, Freschi G, Bucciarelli G, Magli MC and Boncinelli E: HOX gene expression in normal and neoplastic human kidney. Int J Cancer 51: 892-897, 1992.

11. De Vita G, Barba P, Odartchenko N, et al: Expression of homeo-box-containing genes in primary and metastatic colorectal cancer. Eur J Cancer 29A: 887-893, 1993.

12. Freschi G, Taddei A, Bechi P, et al: Expression of HOX homeobox genes in the adult human colonic mucosa (and colorectal cancer?). Int J Mol Med 16: 581-587, 2005.

13. Vider BZ, Zimber A, Hirsch D, et al: Human colorectal carcinogenesis is associated with deregulation of homeobox gene expression. Biochem Biophys Res Commun 232: 742-748, 1997.

14. Care A, Silvani A, Meccia E, et al: HOXB7 constitutively activates basic fibroblast growth factor in melanomas. Mol Cell Biol 16: 4842-4851, 1996.

15. Miller GJ, Miller HL, van Bokhoven A, et al: Aberrant HOXC expression accompanies the malignant phenotype in human prostate. Cancer Res 63: 5879-5888, 2003.

16. Waltregny D, Alami Y, Clausse N, de Levin J and Castronovo V: Overexpression of the homeobox gene HOXC8 in human prostate cancer correlates with loss of tumor differentiation. Prostate 50: 162-169, 2002.

17. Cantile M, Cindolo L, Napodano G, Altieri V and Cillo C: Hyperexpression of locus $\mathrm{C}$ genes in the HOX network is strongly associated in vivo with human bladder transitional cell carcinomas. Oncogene 22: 6462-6468, 2003.

18. Makiyama K, Hamada J, Takada M, et al: Aberrant expression of HOX genes in human invasive breast carcinoma. Oncol Rep 13: 673-679, 2005.

19. Svingen T and Tonissen KF: Altered HOX gene expression in human skin and breast cancer cells. Cancer Biol Ther 2: 518-523, 2003.

20. Liu DB, Gu ZD, Cao XZ, Liu H and Li JY: Immunocytochemical detection of HoxD9 and $\mathrm{Pbx} 1$ homeodomain protein expression in Chinese esophageal squamous cell carcinomas. World J Gastroenterol 11: 1562-1566, 2005.

21. Li H, Huang CJ and Choo KB: Expression of homeobox genes in cervical cancer. Gynecol Oncol 84: 216-221, 2002.

22. Cillo C, Cantile M, Mortarini R, Barba P, Parmiani G and Anichini A: Differential patterns of HOX gene expression are associated with specific integrin and ICAM profiles in clonal populations isolated from a single human melanoma metastasis. Int J Cancer 66: 692-697, 1996.

23. Cillo C, Faiella A, Cantile M and Boncinelli E: Homeobox genes and cancer. Exp Cell Res 248: 1-9, 1999.

24. Takahashi Y, Hamada J, Murakawa K, et al: Expression profiles of 39 HOX genes in normal human adult organs and anaplastic thyroid cancer cell lines by quantitative real-time RT-PCR system. Exp Cell Res 293: 144-153, 2004.

25. Giancotti FG and Ruoslahti E: Integrin signaling. Science 285 : 1028-1032, 1999.

26. Guo W and Giancotti FG: Integrin signalling during tumour progression. Nat Rev Mol Cell Biol 5: 816-826, 2004. 
27. Bissell MJ and Radisky D: Putting tumours in context. Nat Rev Cancer 1: 46-54, 2001.

28. Mercurio AM and Rabinovitz I: Towards a mechanistic understanding of tumor invasion - lessons from the alpha6beta4 integrin. Semin Cancer Biol 11: 129-141, 2001.

29. Gulubova $M$ and Vlaykova T: Immunohistochemical assessment of fibronectin and tenascin and their integrin receptors alpha5beta1 and alpha9beta1 in gastric and colorectal cancers with lymph node and liver metastases. Acta Histochem 108: 25-35, 2006.

30. Takatsuki H, Komatsu S, Sano R, Takada Y and Tsuji T: Adhesion of gastric carcinoma cells to peritoneum mediated by alpha3beta1 integrin (VLA-3). Cancer Res 64: 6065-6070, 2004.

31. Koike N, Todoroki T, Komano H, et al: Invasive potentials of gastric carcinoma cell lines: role of alpha 2 and alpha 6 integrins in invasion. J Cancer Res Clin Oncol 123: 310-316, 1997.

32. Sakakura C, Hagiwara A, Nakanishi M, et al: Differential gene expression profiles of gastric cancer cells established from primary tumour and malignant ascites. Br J Cancer 87: 1153-1161, 2002.

33. Livak KJ and Schmittgen TD: Analysis of relative gene expression data using real-time quantitative PCR and the 2(-Delta Delta C(T)) method. Methods 25: 402-408, 2001.

34. Wingo PA, Cardinez CJ, Landis SH, et al: Long-term trends in cancer mortality in the United States, 1930-1998. Cancer 97: 3133-3275, 2003.

35. Maeda K, Hamada J, Takahashi Y, et al: Altered expressions of HOX genes in human cutaneous malignant melanoma. Int $\mathbf{J}$ Cancer 114: 436-441, 2005.

36. Boudreau NJ and Varner JA: The homeobox transcription factor Hox D3 promotes integrin alpha5betal expression and function during angiogenesis. J Biol Chem 279: 4862-4868, 2004.

37. Davis AP, Witte DP, Hsieh-Li HM, Potter SS and Capecchi MR: Absence of radius and ulna in mice lacking hoxa-11 and hoxd11. Nature 375: 791-795, 1995.
38. Schwab K, Hartman HA, Liang HC, Aronow BJ, Patterson LT and Potter SS: Comprehensive microarray analysis of Hoxa11/ Hoxd11 mutant kidney development. Dev Biol 293: 540-554, 2006.

39. Wong KH, Wintch HD and Capecchi MR: Hoxa11 regulates stromal cell death and proliferation during neonatal uterine development. Mol Endocrinol 18: 184-193, 2004.

40. Leroy-Dudal J, Demeilliers C, Gallet O, et al: Transmigration of human ovarian adenocarcinoma cells through endothelial extracellular matrix involves alphav integrins and the participation of MMP2. Int J Cancer 114: 531-543, 2005.

41. Zhang Y, Lu H, Dazin P and Kapila Y: Functional differences between integrin alpha4 and integrins alpha5/alphav in modulating the motility of human oral squamous carcinoma cells in response to the $\mathrm{V}$ region and heparin-binding domain of fibronectin. Exp Cell Res 295: 48-58, 2004.

42. Lim M, Guccione S, Haddix T, et al: alpha(v)beta(3) integrin in central nervous system tumors. Hum Pathol 36: 665-669, 2005.

43. Koistinen P, Ahonen M, Kahari VM and Heino J: alphaV integrin promotes in vitro and in vivo survival of cells in metastatic melanoma. Int J Cancer 112: 61-70, 2004.

44. Ahmed N, Riley C, Rice G and Quinn M: Role of integrin receptors for fibronectin, collagen and laminin in the regulation of ovarian carcinoma functions in response to a matrix microenvironment. Clin Exp Metastasis 22: 391-402, 2005.

45. Bieritz B, Spessotto P, Colombatti A, Jahn A, Prols F and Hartner A: Role of alpha8 integrin in mesangial cell adhesion, migration, and proliferation. Kidney Int 64: 119-127, 2003.

46. Uesugi $\mathrm{N}$ and Sakata N: Role of integrins, including alpha8, for neointima formation after vascular injury. Cardiovasc Res 65: 766-767, 2005. 